\title{
Língua e Literaturas Espanhola \\ e Hispano-Americanas
}

MARIO M. GONZÁLEZ

A

habilitaçăo em Espanhol pela antiga Faculdade de Filosofia, Ciências e Letras constou do Decreto 6283, de 25/01/34, que criou a USP. As disciplinas Língua Espanhola e Literatura Espanhola passaram a ser oferecidas a partir de 1940 - na Cadeira do mesmo nome - no Curso de Línguas Estrangeiras. Com a criação, em 1942, da habilitação em Letras Neolatinas - que destinava dois anos ao estudo dessas disciplinas -, a Literatura Hispano-Americana foi incorporada ao nome da Cadeira. A partir de 1964, passou a existir a habilitação em Espanhol, com a presença das mencionadas disciplinas ao longo dos quatro anos do curso. Em 1970, com à reforma universitária, os docentes da antiga Cadeira foram incorporados, junto com os das similares de Alemão, Francês, Inglês e Italiano, para compor o Departamento de Letras Modernas, situação que perdura até hoje.

$\mathrm{Na}$ evolução dos estudos relativos ao Espanhol e suas literaturas na FFLCH/USP, cabe distinguir, até esta data, três momentos: um inicial, até 1963; outro intermediário, dessa data até a implantação da atual pós-graduação, em 1978; e a etapa posterior de desenvolvimento desses estudos.

De 1940 a 1944, a Cadeira contou com apenas um professor contratado; em 1944 ganhou um assistente e, a partir de 1949 passou a contar com um auxiliar de ensino; no início dos anos 60 , além do catedrático, com um professor colaborador e dois assistentes. Até 1951, os programas de Literatura limitavam-se à Literatura Espanhola. Em 1952, incorporaram o Romantismo e o Post-Romantismo (sic) hispano-americanos. A partir de 1960, a Literatura Hispano-Americana aparece como disciplina independente dentro da Cadeira. Nessa primeira etapa, é claro o predomínio dos estudos literários. Ao ensino da língua espanhola destinava-se apenas um ano em $1961 \mathrm{e}$ dois em 1962. A literatura hispano-americana, por sua vez, aos poucos iria ganhando espaço equivalente ao destinado à espanhola. Por outra parte, entre 1957 e 1963, 
foram lançados cinco Boletins da Cadeira, todos eles contendo textos de autoria de seu titular, coletâneas de artigos, na maioria dos casos.

Em 1963 foi criado o Centro de Estudos Hispânicos, com finalidade de apoio à pesquisa e de extensáo universitária. Por outra parte, no mesmo ano, um convênio desse Centro com o Instituto de Cultura Hispanica, de Madri, criou o Instituto de Cultura Hispânica de Sáo Paulo, que existiria até 1977. Nesse Instituto, instalado à avenida Brigadeiro Luiz Antônio no 871, os docentes contaram, até 1970, além de local de trabalho, com uma biblioteca cujo acervo superava o da própria Cadeira. Igualmente, um setor de recursos audiovisuais com 10.000 slides viabilizou a elaboraçáo de cerca de $\mathbf{2 5 0}$ programas audiovisuais; a existência de uma gráfica própria permitiu a publicaçáo de numerosas apostilas destinadas aos alunos e, inclusive, de alguns livros; em 1977 chegou a ser lançado o número 1 de Convergencia - Revista IberoAmericana de Cultura. O convênio com Madri permitiu enviar regularmente professores ou ex-alunos para pesquisas ou estudos de especialização na Espanha.

Em 1965 foi preenchido, por concurso público, o cargo de Catedrático. Além disso, entre 1960 a 1973 , foram defendidas as primeiras teses, dentro ao antigo regime de pós-graduaçăo: três dissertaçóes de mestrado (duas de Literatura Espanhola e uma de Língua); cinco teses de doutoramento (três de Literatura Espanhola, uma de HispanoAmericana e uma de Língua); além de uma de Livre-Docência, em Literatura Hispano-Americana.

Nessa segunda etapa, há um forte aumento quantitativo do corpo docente; ao ser criado o Departamento de Letras Modernas, em 1970, a área dispunha de seis docentes; em 1977, já contava com 13 professores. Ao mesmo tempo, estabeleceu-se uma distribuição eqüitativa da carga horária entre as três disciplinas da área e fixou-se a distribuiçăo do trabalho dos docentes levando-se em conta a sua especializaçáo em uma delas.

A reforma universitária de 1969, no entanto, e a implantação do atual regime de pós-graduação encontraram a área, circunstancialmente, carente da massa crítica indispensável para a sua adoçáo. Assim, apenas em 1977 foi possível solicitar da Universidade o credenciamento da pós-graduaçáo na especialidade. Embora esta fosse criada como área de Lingua Espanbola e Literatura Espanbola e Hispano-Americana os estudos nesse nível centraram-se exclusivamente nas literaturas, ao ponto de posteriormente ter sido o nome do curso mudado para Literaturas Espanbola e Hispano-Americana, atendendo assim, também, à independência no tratamento de ambas as literaturas. Nesse sentido apontam as dez 
teses de doutoramento e as $\mathbf{2 3}$ dissertaçóes de mestrado defendidas desde então na área, bem como as pesquisas dos atuais alunos ( 16 de doutoramento e 15 de mestrado) e dos docentes de pós-graduação (dois titulares, três livre-docentes e quatro doutores). Atualmente está em marcha um processo de revigoração dos estudos de Língua Espanhola, mediante o desenvolvimento de pesquisas a partir da Lingǘística Aplicada. Dessa forma, as linhas de pesquisa, na área referem-se à Literatura Espanhola (medieval, clássica e contemporânea) e à Literatura Hispano-Americana (contemporânea e nas suas relaçóes com a cultura); outra linha de pesquisa destina-se ao estudo comparado das literaturas iberoamericanas. Parte da produçăo da área é veiculada no Anudrio Brasileño de Estudios Hispánicos, editado em São Paulo pela Consejerta de Educación da Embaixada da Espanha, publicaçáo que, em 1994, atinge seu quarto número.

De 1982 a 1990, a área contaria com 14 docentes. Hoje a integram um total de 13 professores. É de se salientar que o maior desenvolvimento da pesquisa, a partir de 1978 , coincide com a progressiva extensăo do regime de trabalho da totalidade dos docentes da área à dedicação exclusiva. As principais realizações (limitando-nos aos trabalhos dos atuais docentes da área de Pós-Graduação que, em sua maioria, foram publicados em livro) dentro do conjunto de linhas de pesquisa, podem ser assim sintetizadas: a análise do conflito dramático na peça Bodas de sangre, de Federico García Lorca; a determinaçáo do conceito de realismo maravilhoso, a partir do estudo da obra de Alejo Carpentier; o estudo comparativo dos movimentos de vanguarda latino-americanos, pela primeira vez integrando o modernismo brasileiro; o estudo da noçáo de fronteira no Cantar de mio Cia e nas crônicas medievais; o estudo da obra de Lezama Lima; o estudo da poesia de Vicente Huidobro; a análise de Don Quijote de la Mancha à luz do maneirismo e o processo de construçáo da personagem; o estudo da obra de Virgilio Pińera; o estudo do romance picaresco espanhol e de suas correspondências na literatura brasileira; a análise da presença do Brasil na obra de Juan Valera.

Os docentes da área participam ativamente de um trabalho de integraçáo com os países hispano-americanos, especialmente através do Centro Angel Rama que, em 1991, organizou um Seminário Internacional sobre Literatura e História na América Latina, com a presença de 14 especialistas estrangeiros como convidados, cujas atas foram publicadas pela Edusp.

A área constitui o único curso específico de pós-graduaçăo existente no país na especialidade. Assim, é importante centro de formaçăo 
de docentes de outras universidades brasileiras (12\% das dissertaçóes e teses defendidas e 41,9\% dos atuais alunos); igualmente, atrai de maneira significativa o interesse de graduados provindos de outros países latino-americanos (24\% das dissertaçōes e teses defendidas e $22,5 \%$ dos atuais alunos). Ademais, a área conta regularmente com a colaboração de professores visitantes: entre 1987 e 1994, recebeu um total de 14 visitantes estrangeiros que ministraram cursos, ou seja, na média de quase um professor por semestre.

Mario M. Gonzatles é professor do Departamento de Letras Modernas da Faculdade de Filosofia, Letras e Ciências Humanas da USP. 